\title{
Pupuk Hayati Bacillus sp. Meningkatkan Produktivitas Tanaman Karet (Hevea brasiliensis Muell Arg.)
}

\section{Bacillus sp. Biological Fertilizer Increase Productivity of Rubber Plant (evea brasiliensis Muell Arg.)}

\section{Sugiyanta* dan Octafiani Septianti}

\author{
Departemen Agronomi dan Hortikultura, Fakultas Pertanian, Institut Pertanian Bogor \\ (Bogor Agricultural University), J1. Meranti, Kampus IPB Darmaga, Bogor 16680, Indonesia \\ Telp. \& Faks.62-251-8629353 e-mail agrohort@apps.ipb.ac.id \\ *Penulis Korespondensi : mr_sugiyanta@yahoo.co.id
}

Disetujui : 22 Mei 2018 / Published Online 2 Januari 2019

\begin{abstract}
Natural rubber (Hevea brasiliensis Muell Arg.) is one of the important plantation commodities in Indonesia. The problem of Indonesian rubber is the low productivity and quality of rubber produced, especially by smallholder rubber farmers. This study aims to determine the effect of Bacillus biofertilizer on the productivity of rubber crops. The study was divided into two experiments based on the application of Bacillus biofertilizer ie, swiped and sprayed. The experiment was conducted in rubber plantation, experimental plant of IPB Cikabayan, Bogor. Experiment 1 (Bacillus biofertilizer with swipe application) was conducted from October to December 2016. This experiment was arranged in a 1-factor randomized block design that is the application of Bacillus biofertilizer and consists of 2 levels of treatment (control and $4 \mathrm{~g}$ of Bacillus/plant/application biofertilizer). Each treatment was repeated 5 times. Experiment 2 (Bacillus biofertilizer with spray application) was conducted in December 2017 to February 2018. This experiment was arranged in a 1-factor randomized block design (Bacillus biofertilizer application) and consisted of 5 levels of treatment (control, $1 \mathrm{ml}, 2 \mathrm{ml}, 3 \mathrm{ml}$, and $4 \mathrm{ml}$ of Bacillus biofertilizer/10 $\mathrm{ml}$ water /plant/application). Each treatment was repeated 3 times. The results of experiments 1 and 2 show that the application of Bacillus significantly increased latex production, dry rubber production per plant, and dry rubber yield per hectare, but no effect on dry rubber content (DRC).
\end{abstract}

Keywords: bacteria, growth regulators, field tapping, latex

\begin{abstract}
ABSTRAK
Karet alam (Hevea brasiliensis Muell Arg.) merupakan salah satu komoditas perkebunan yang penting di Indonesia. Permasalahan karet Indonesia adalah rendahnya produktivitas dan mutu karet yang dihasilkan, khususnya oleh petani karet rakyat. Penelitian ini bertujuan untuk mengetahui pengaruh pemberian pupuk hayati Bacillus pada produktivitas tanaman karet. Penelitian dibagi menjadi dua percobaan berdasarkan cara aplikasi pupuk hayati Bacillus yaitu dioles dan disemprot. Percobaan dilakukan di kebun karet, kebun percobaan IPB Cikabayan, Bogor. Percobaan 1 (aplikasi pupuk hayati Bacillus dioles) dilakukan pada bulan Oktober hingga Desember 2016. Percobaan ini disusun dalam rancangan acak kelompok 1 faktor yaitu aplikasi pupuk hayati Bacillus dan terdiri atas 2 taraf perlakuan (kontrol dan $4 \mathrm{~g}$ pupuk hayati Bacillus/tanaman/aplikasi). Setiap perlakuan diulang sebanyak 5 kali. Percobaan 2 (aplikasi pupuk hayati Bacillus disemprot) dilakukan pada bulan Desember 2017 hingga Februari 2018. Percobaan ini disusun dalam rancangan acak kelompok 1 faktor (aplikasi pupuk hayati Bacillus) dan terdiri atas 5 taraf perlakuan (kontrol, $1 \mathrm{ml}, 2 \mathrm{ml}, 3 \mathrm{ml}$, dan $4 \mathrm{ml}$ pupuk hayati Bacillus sp./10 $\mathrm{ml}$ air/tanaman/aplikasi). Setiap perlakuan diulang sebanyak 3 kali. Hasil percobaan 1 dan 2 menunjukkan bahwa aplikasi pupuk hayati Bacillus nyata meningkatkan produksi lateks, produksi karet kering per tanaman, dan hasil karet kering per hektar, tetapi tidak berpengaruh terhadap kadar karet kering (KKK).
\end{abstract}

Kata kunci: bakteri, bidang sadap, lateks, zat pengatur tumbuh 


\section{PENDAHULUAN}

Karet alam (Hevea brasiliensis Muell Arg.) merupakan salah satu komoditas perkebunan yang penting di Indonesia. Karet merupakan tanaman yang dapat menghasilkan metabolit sekunder berupa getah (lateks) (Pusari dan Haryanti, 2014). Cairan lateks pada tanaman karet merupakan sitoplasma dari sel khusus yang disebut laticifer yang terletak dalam pembuluh floem karet, sedangkan struktur partikel karet dan vakuola kecil yang disebut lutoid merupakan komponen terbesar dari lateks. Metabolisme di dalam laticifer harus mampu menghasilkan dan mengkompensasi kehilangan sitoplasma (30 sampai $300 \mathrm{ml}$ ) setiap kali terjadi penyadapan yang biasanya dilakukan 2 sampai 3 kali dalam seminggu (D'Auzac et al., 1982).

Permasalahan karet Indonesia adalah rendahnya produktivitas dan mutu karet yang dihasilkan, khususnya oleh petani karet rakyat. Hal tersebut disebabkan oleh teknik budidaya dan sistem eksploitasi yang masih kurang baik (Syakir et al., 2010). Petani karet biasanya menggunakan zat perangsang sadap lateks (stimulan). Penggunaan stimulan bertujuan untuk meningkatkan produksi lateks dan menekan biaya eksploitasi (Galingging et al., 2017). Zat stimulan dapat meningkatkan produksi lateks melalui beberapa cara yaitu meningkatkan permeabilitas membran, mengakselerasi metabolisme sukrosa, memperpanjang waktu pengaliran lateks, dan memodulasi aktivitas enzim seperti glutamine synthase dan HGMS (Zhu dan Zhang, 2009). Stimulan yang sering digunakan yaitu stimulan berbahan aktif etilen (etefon) dengan berbagai merk dagang (Syakir et al., 2010). Penggunaan stimulan etefon dalam jangka panjang akan memberikan dampak berkurangnya masa eksploitasi karet, peningkatan presentase kering alur sadap (KAS), terhambatnya perkembangan lilit batang, dan penurunan produktivitas tanaman (Tistama dan Siregar, 2005).

Rendahnya produktivitas dan mutu karet juga disebabkan oleh serangan penyakit. Beberapa penyakit yang sering menyerang tanaman karet antara lain penyakit jamur akar putih (JAP), penyakit batang kanker garis, gugur daun, penyakit layu fusarium,dan jamur upas (Iskarlia et al., 2014). Penyakit jamur akar putih merupakan penyebab terbesar kematian tanaman karet karena dapat menyerang mulai dari pembibitan hingga tanaman tua (Maulana et al., 2016). Penyakit bidang sadap yang sering menyerang tanaman karet yaitu kering alur sadap (KAS) dan mouldy rot. Penyebab KAS adalah over exploitation yang memicu peningkatan senyawa radikal yang menyebabkan koagulasi lateks di dalam pembuluh lateks dan pembentukan sel tilasoid. Tanaman karet yang terserang KAS memiliki kandungan unsur hara makro dan mikro yang lebih rendah baik di dalam lateks maupun kulit dibandingkan dengan tanaman sehat (Andriyanto dan Tistama, 2014). Penyakit mouldy rot disebabkan oleh jamur Ceratocytis fimbriata. Mouldy rot menyebabkan muncul lapisan beludru pada bidang sadap, kulit membusuk hitam kecoklatan, dan alur sadap berwarna hitam (Sulistiani dan Muludi, 2018).

Peningkatan produksi lateks seharusnya dilakukan dengan meningkatkan serapan nutrisi, mengaplikasikan zat pengatur tumbuh, dan sekaligus mencegah kerusakan bidang sadap karena serangan jamur. Salah satu cara yang dapat dilakukan yaitu mengaplikasikan pupuk hayati Bacillus sp. pada bidang sadap. Kandungan bakteri Bacillus sp. dalam pupuk hayati dapat meningkatkan serapan nutrisi, menghasilkan zat pengatur tumbuh, dan mengurangi serangan penyakit bidang sadap yang disebabkan oleh jamur. Bacillus sp. dapat menghasilkan fitohormon yang dapat membantu pertumbuhan tanaman baik secara langsung maupun tidak langsung. Secara tidak langsung fitohormon dari bakteri menghambat aktivitas patogen pada tanaman, sedangkan pengaruh secara langsung fitohormon adalah meningkatkan pertumbuhan tanaman dan bertindak sebagai fasilitator dalam penyerapan beberapa unsur hara (Gupta, 1999). Bacillus sp. dapat menghambat perkecambahan konidia, pembentukan apresoria patogen, menghambat perkembangan haustoria dan pemanjangan miselia (Gao et al., 2015). Bacillus sp. memiliki beberapa kelebihan dibandingkan dengan mikroorganisme lain. Bacillus sp. dapat menghasilkan endospora yang tahan terhadap kondisi lingkungan yang ekstrim dan dapat bertahan hidup lama (Suriani dan Muis, 2016).

\section{BAHAN DAN METODE}

\section{Percobaan 1 (Aplikasi Pupuk Hayati Bacillus Dioles)}

Percobaan ini dilaksanakan di Kebun Karet, Kebun Percobaan IPB Cikabayan Darmaga Bogor pada bulan Oktober-Desember 2016. Bahan yang digunakan adalah tanaman karet klon GT-1 dengan umur sadap ke 10 (tahun tanam 2001) dan pupuk hayati Bacillus yang mengandung 10 tipe baktei Bacillus (Bacillus catenulatus, Bacillus cereus, Bacillus drentensis, Bacillus firmus, Bacillus flexus, Bacillus Megaterium, Bacillus niacini, Bacillus subtilis, Bacillus tequilensis, dan 
Bacillus thuringiensis). Alat-alat yang digunakan adalah seperangkat alat sadap (pisau sadap, mangkuk, ember), gelas ukur, kuas, timbangan dan oven (untuk menentukan kadar karet kering lateks). Penelitian ini menggunakan rancangan acak kelompok dengan I faktor (aplikasi pupuk hayati Bacillus) dan terdiri atas 2 taraf perlakuan yaitu kontrol dan $4 \mathrm{~g}$ pupuk hayati Bacillus/tanaman/aplikasi (1440 $\left.\mathrm{g} \mathrm{ha}^{-1}\right)$. Setiap perlakuan diulang sebanyak 5 kali. Setiap satu satuan percobaan terdiri atas 3 tanaman karet siap sadap yang cukup seragam. Dengan demikian dalam percobaan ini terdapat 30 pohon karet yang digunakan untuk pengujian. Notasi sadap yang digunakan adalah $1 / 2 \mathrm{~S} \mathrm{~d} / 3$. Aplikasi pupuk hayati Bacillus pertama diberikan satu hari sebelum sadap. Aplikasi kedua dan seterusnya diberikan dengan interval 1 minggu sekali. Aplikasi pupuk hayati Bacillus dilakukan dengan cara mengoleskan pupuk pada alur sadap dengan terlebih dahulu mengambil lateks yang membeku pada alur sadap. Penyadapan pertama dilakukan 1 hari setelah aplikasi pupuk hayati Bacillus. Penyadapan berikutnya dilakukan setiap 3 hari sekali. Perlakuan kontrol merupakan penyadapan biasa tanpa pemberian pupuk hayati Bacillus. Pengamatan dilakukan selama 3 bulan.

\section{Percobaan 2 (Aplikasi Pupuk Hayati Bacillus Disemprot)}

Percobaan ini dilaksanakan di Kebun Karet, Kebun Percobaan IPB Cikabayan Darmaga Bogor pada bulan Desember 2017-Februari 2018. Bahan yang digunakan adalah tanaman karet klon GT-1 dengan umur sadap ke 10 (tahun tanam 2001) dan pupuk hayati Bacillus. Alat-alat yang digunakan adalah seperangkat alat sadap (pisau sadap, mangkuk, ember), gelas ukur, semprotan, suntikan, timbangan dan oven (untuk menentukan kadar karet kering lateks). Penelitian ini menggunakan rancangan acak kelompok 1 faktor (aplikasi pupuk hayati Bacillus) dan terdiri atas 5 taraf perlakuan yaitu kontrol, $1 \mathrm{ml}, 2 \mathrm{ml}, 3 \mathrm{ml}$, dan $4 \mathrm{ml}$ pupuk hayati Bacillus $/ 10 \mathrm{ml}$ air/tanaman. Setiap perlakuan diulang sebanyak 3 kali. Setiap satu satuan percobaan terdiri atas 3 tanaman karet siap sadap yang cukup seragam. Dengan demikian dalam percobaan ini terdapat 45 pohon karet yang digunakan untuk pengujian. Notasi sadap yang digunakan adalah $1 / 2 \mathrm{~S} \mathrm{~d} / 3$. Aplikasi pupuk hayati pertama diberikan satu hari sebelum sadap. Aplikasi kedua dan seterusnya diberikan dengan interval 1 minggu sekali. Aplikasi pupuk hayati Bacillus dilakukan dengan cara menyemprotkan pupuk pada alur sadap dengan terlebih dahulu mengambil lateks yang membeku pada alur sadap.
Penyadapan pertama dilakukan 1 hari setelah aplikasi pupuk hayati Bacillus. Penyadapan berikutnya dilakukan setiap 3 hari sekali. Perlakuan kontrol merupakan penyadapan biasa tanpa pemberian pupuk hayati Bacillus. Pengamatan dilakukan selama 3 bulan.

\section{Peubah Pengamatan dan Analisis Data}

Peubah yang diamati pada kedua percobaan ini meliputi produksi lateks (ml) setiap kali sadap, kadar karet kering (KKK) setiap kali sadap (\%), produksi karet kering per tanaman (g) yang merupakan hasil perkalian volume lateks dengan KKK pada setiap kali sadap, dan hasil karet kering per hektar per tahun $\left(\mathrm{kg} \mathrm{ha}^{-1}\right)$. Hasil karet kering per hektar per tahun diperoleh dengan menggunakan asumsi tanaman disadap 3 hari sekali dengan populasi tanaman per hektar 360 tanaman. Data dianalisis secara statistik menggunakan sidik ragam dan uji Duncan Multiple Range Test (DMRT) pada taraf $5 \%$.

\section{HASIL DAN PEMBAHASAN}

\section{Aplikasi Pupuk Hayati Bacillus dengan Cara Dioles}

\section{Produksi Lateks}

Aplikasi pupuk hayati Bacillus dengan cara dioles nyata meningkatkan produksi lateks mulai dari sadapan ke-1 hingga sadapan ke-15 jika dibandingkan perlakuan kontrol. Produksi lateks pada perlakuan pupuk hayati Bacillus berkisar antara 66.7 hingga $91.1 \mathrm{ml}$ sedangkan perlakuan kontrol hanya mampu menghasilkan volume lateks sekitar 38.9 hingga $55.6 \mathrm{ml}$ per tanaman setiap kali sadap. Peningkatan yang terjadi hampir $100 \%$ dibandingkan hasil sadapan tanpa perlakuan pupuk hayati Bacillus (Tabel 1). Produksi lateks pada perlakuan pupuk hayati Bacillus lebih tinggi karena pupuk hayati Bacillus yang digunakan mengandung 10 tipe bakteri Bacillus yang dapat menjadi sumber pupuk, pengendali hama dan penyakit, dan menghasilkan hormon yang dapat memacu pertumbuhan tanaman. Beberapa spesies bakteri dari genus Bacillus memiliki potensi dalam mengikat nitrogen dan menghasilkan hormon IAA (Rosenblueth dan Martinez-Romero, 2008). IAA merupakan fitohormon kelompok auksin alami yang berperan sebagai pemacu pertumbuhan tanaman karena berperan meregulasi banyak proses fisiologi, seperti pembelahan, diferensiasi sel, dan sistesis protein (Idris, 2007). Karakter fisiologi pada tanaman karet erat hubungannya dengan kemampuan tanaman dalam mensintesis asimilat menjadi bahan pembentuk 
lateks. Karakter fisiologi yang sangat penting dalam pembentukan lateks diantaranya adalah kandungan sukrosa, fosfat anorganik, dan kadar tiol (Woelan et al., 2013). Bacillus sp. juga dapat menghasilkan senyawa-senyawa yang bersifat antibiotis seperti enzim kitinase yang dapat menghidrolisis dinding sel jamur (Wang dan Chang, 1997), siderofor, dan antibiotik lainnya yang dapat menghambat perkembangan pathogen (Habazar dan Yaherwandi, 2006).

\section{Kadar Karet Kering (KKK)}

Kadar karet kering (KKK) merupakan kandungan padatan karet per satuan berat (\%). Umumnya lateks kebun hasil penyadapan mempunyai kadar karet kering sekitar 20-35\% (Purbaya et al., 2011). Secara umum kadar karet kering tidak dipengaruhi oleh perlakuan pupuk hayati Bacillus. Kadar karet kering perlakuan kontrol berkisar antara 29.0 hingga 31.0\% dan perlakuan pupuk hayati Bacillus menghasilkan kadar karet kering berkisar antara 29.0 hingga $30.7 \%$ (Tabel 1).

\section{Produksi Karet Kering per Tanaman}

Aplikasi pupuk hayati Bacillus nyata meningkatkan produksi karet kering per tanaman sejak sadapan pertama hingga sadapan ke-15. Perlakuan kontrol hanya mampu menghasilkan 11.2 sampai $17.1 \mathrm{~g}$ karet kering per tanaman per sadapan sedangkan pada perlakuan yang memperoleh aplikasi pupuk hayati Bacillus mampu menghasilkan karet kering antara 20.5 sampai $27.7 \mathrm{~g}$ per tanaman per sadapan (Tabel 1). Peningkatan produksi karet kering pada perlakuan pupuk hayati Bacillus tersebut disebabkan oleh peningkatan volume lateks yang dihasilkan. Peningkatan produksi karet kering setiap kali sadap meningkat rata-rata $100 \%$ dibandingkan tanaman yang tidak memperoleh perlakuan pupuk hayati Bacillus. Volume bidang sadap pada perlakuan pupuk hayati Bacillus lebih tinggi karena bakteri Bacillus sp. yang terdapat pada pupuk hayati Bacillus yang digunakan dapat menekan pertumbuhan penyakit bidang sadap yang disebabkan oleh jamur. Penyakit bidang sadap yang disebabkan oleh jamur meliputi penyakit Mouldy Rot yang disebabkan oleh jamur Ceratocytis fimbriata dan kanker garis yang dise babkan oleh jamur Phytophtora palmivora (Semangun, 1990). Hasil penelitian Jatnika et al. (2013) menunjukkan bahwa perlakuan bakteri Bacillus sp. dapat menekan sporulasi jamur patogen. Bakteri Bacillus sp. juga dapat meningkatkan pertumbuhan tanaman karet melalui zat pengatur tumbuh yang dihasilkannya, sehingga lateks yang dihasilkan lebih banyak. Selain itu, pupuk organik hayati juga dapat meningkatkan pertumbuhan tanaman karet karena dapat menyediakan unsur hara yang dibutuhkan tanaman.

Tabel 1. Pengaruh perlakuan pupuk hayati Bacillus dengan aplikasi oles terhadap produksi lateks per tanaman, kadar karet kering, dan produksi karet kering/tanaman

\begin{tabular}{|c|c|c|c|c|c|c|}
\hline \multirow{2}{*}{$\begin{array}{l}\text { Sadapan } \\
\text { ke- }\end{array}$} & \multicolumn{2}{|c|}{ Produksi Lateks per Tanaman (ml) } & \multicolumn{2}{|c|}{ Kadar Karet Kering (\%) } & \multicolumn{2}{|c|}{ Produksi Karet Kering/Tanaman $(\mathrm{g})$} \\
\hline & Kontrol & $\begin{array}{c}4 \mathrm{~g} / \text { pohon pupuk hayati } \\
\text { Bacillus }\end{array}$ & Kontrol & $\begin{array}{c}4 \mathrm{~g} / \text { pohon pupuk } \\
\text { hayati Bacillus }\end{array}$ & Kontrol & $\begin{array}{l}4 \mathrm{~g} / \text { pohon pupuk } \\
\text { hayati Bacillus }\end{array}$ \\
\hline 1 & $44.4 \mathrm{~b}$ & 83.3a & $30.7 \mathrm{a}$ & $29.0 \mathrm{a}$ & $13.7 \mathrm{~b}$ & 24.1a \\
\hline 2 & $44.4 \mathrm{~b}$ & $77.8 \mathrm{a}$ & $30.7 \mathrm{a}$ & $30.7 \mathrm{a}$ & $13.7 \mathrm{~b}$ & $23.7 \mathrm{a}$ \\
\hline 3 & $38.9 b$ & $66.7 \mathrm{a}$ & $29.0 \mathrm{~b}$ & $30.7 \mathbf{a}$ & $11.2 \mathrm{~b}$ & $20.6 a$ \\
\hline 4 & $46.7 \mathrm{~b}$ & $72.2 \mathrm{a}$ & $30.3 a$ & $30.0 \mathrm{a}$ & $14.2 \mathrm{~b}$ & 21.8a \\
\hline 5 & $47.8 \mathrm{~b}$ & $83.3 \mathrm{a}$ & $30.0 \mathrm{a}$ & $30.7 \mathrm{a}$ & $14.2 \mathrm{~b}$ & $25.3 \mathrm{a}$ \\
\hline 6 & $38.9 b$ & $68.9 \mathrm{a}$ & $30.0 \mathrm{a}$ & $30.0 \mathrm{a}$ & $11.6 \mathrm{~b}$ & $20.5 a$ \\
\hline 7 & $41.1 \mathrm{~b}$ & 83.3a & $29.7 \mathrm{a}$ & $30.3 \mathrm{a}$ & $12.2 \mathrm{~b}$ & 25.1a \\
\hline 8 & $55.6 \mathrm{~b}$ & 83.3a & $31.0 \mathrm{a}$ & $29.3 a$ & $17.1 \mathrm{~b}$ & $24.2 \mathrm{a}$ \\
\hline 9 & $47.8 \mathrm{~b}$ & 88.9a & $30.0 \mathrm{a}$ & $31.0 \mathrm{a}$ & $14.2 \mathrm{~b}$ & $27.3 \mathrm{a}$ \\
\hline 10 & $38.9 b$ & $86.7 \mathrm{a}$ & $30.3 \mathrm{a}$ & $30.0 \mathrm{a}$ & $11.8 \mathrm{~b}$ & 26.1a \\
\hline 11 & $44.4 \mathrm{~b}$ & $74.4 a$ & $30.3 \mathrm{a}$ & $30.0 \mathrm{a}$ & $13.6 \mathrm{~b}$ & $22.1 \mathrm{a}$ \\
\hline 12 & $41.1 \mathrm{~b}$ & $86.7 \mathrm{a}$ & $30.0 \mathrm{a}$ & $29.3 \mathrm{a}$ & $12.4 \mathrm{~b}$ & $25.4 a$ \\
\hline 13 & $44.4 b$ & $83.3 \mathrm{a}$ & $30.3 \mathrm{a}$ & $29.3 \mathrm{a}$ & $13.6 \mathrm{~b}$ & $24.5 a$ \\
\hline 14 & $45.6 \mathrm{~b}$ & 91.1a & $30.7 \mathrm{a}$ & $30.0 \mathrm{a}$ & $14.1 \mathrm{~b}$ & $27.7 \mathbf{a}$ \\
\hline 15 & $44.4 \mathrm{~b}$ & 87.8a & $29.0 \mathrm{a}$ & $30.0 \mathrm{a}$ & $12.8 \mathrm{~b}$ & $26.4 \mathrm{a}$ \\
\hline
\end{tabular}

Keterangan: Angka-angka yang diikuti oleh huruf yang sama pada baris yang sama, tidak berbeda nyata menurut Uji DMRT taraf 5\% 


\section{Produksi Karet Kering per Hektar per Tahun}

Dengan menggunakan asumsi tanaman disadap 3 hari sekali dengan populasi tanaman per hektar 360 tanaman dan rata-rata produksi karet kering seperti yang tercantum pada Tabel 3, maka dapat diperoleh produktivitas tanaman seperti terlihat pada Gambar 1.

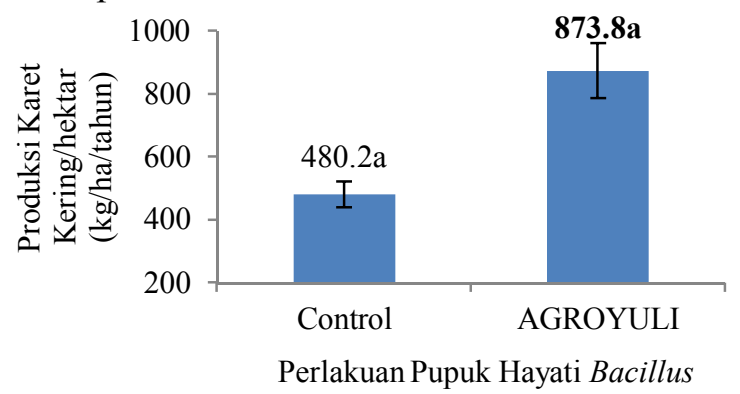

Gambar 1. Pengaruh pupuk hayati Bacillus dengan aplikasi oles terhadap produksi karet kering per hektar per tahun

Aplikasi pupuk hayati Bacillus nyata menghasilkan produktivitas tanaman yang lebih tinggi dibandingkan perlakuan kontrol. Aplikasi pupuk hayati Bacillus dapat menghasilkan sekitar $875.8 \mathrm{~kg}$ karet kering/ha/tahun atau dapat meningkatkan hasil sebesar $82.4 \%$ lebih tinggi dibandingkan perlakuan kontrol yang hanya menghasilkan sekitar $480.2 \quad \mathrm{~kg}$ karet kering/ha/tahun.

\section{Aplikasi Pupuk Hayati Bacillus dengan Cara Disemprot}

\section{Produksi Lateks}

Secara umum, aplikasi 1-4 ml pupuk hayati Bacillus dengan cara disemprot dapat meningkatkan produksi lateks pada 15 kali sadapan. Rata-rata produksi lateks per tanaman pada perlakuan pupuk hayati Bacillus pada 15 sadapan sekitar 47.2-116.7 ml, sedangkan perlakuan kontrol hanya menghasilkan lateks sekitar 41.1-68.9 ml. Aplikasi pupuk hayati Bacillus dapat meningkatkan produksi lateks per tanaman hingga dua kali lipat (Tabel 2). Bacillus sp. dapat menghasilkan zat pengatur tumbuh IAA (Indol-3 asetat acid) yang dapat meningkatkan pertumbuhan tanaman maupun sebagai biokontrol (Lestari et al., 2015). IAA dapat merangsang pembelahan sel, mengatur pembesaran sel, dan memacu penyerapan nutrisi yang berpengaruh terhadap pertumbuhan batang (Tinedung et al., 2014), sehingga produksi lateks dapat meningkat. Kandungan hormon IAA yang dapat dihasilkan bakteri Bacillus sp. mencapai 31.598 ppm (Puspita et al., 2013). Bacillus sp. juga dapat menghasilkan senyawa pendorong atau hormon pertumbuhan tanaman auksin dan sitokinin (Desnawati, 2006).

\section{Kadar Karet Kering (KKK)}

Aplikasi pupuk hayati Bacillus dengan cara disemprot juga tidak berpengaruh terhadap kadar karet kering (KKK). Secara umum, kadar karet kering pada perlakuan 1-4 ml pupuk hayati Bacillus tidak berbeda nyata dengan perlakuan kontrol (tanpa aplikasi pupuk hayati Bacillus) pada sadapan ke-1 sampai 15, hanya perlakuan 4 ml pupuk hayati Bacillus yang menghasilkan KKK nyata lebih tinggi dibandingkan kontrol pa-

Tabel 2. Pengaruh perlakuan pupuk hayati Bacillus dengan aplikasi semprot terhadap produksi lateks per tanaman

\begin{tabular}{|c|c|c|c|c|c|}
\hline \multirow[b]{2}{*}{ Sadapan ke- } & \multicolumn{5}{|c|}{ Produksi Lateks per Tanaman (ml) } \\
\hline & Kontrol & $\begin{array}{c}1 \mathrm{ml} \text { pupuk hayati } \\
\text { Bacillus } / 10 \mathrm{ml} \\
\text { air/tanaman }\end{array}$ & $\begin{array}{c}2 \mathrm{ml} \text { pupuk hayati } \\
\text { Bacillus } / 10 \mathrm{ml} \\
\text { air/tanaman }\end{array}$ & $\begin{array}{c}3 \mathrm{ml} \text { pupuk hayati } \\
\text { Bacillus } / 10 \mathrm{ml} \\
\text { air/tanaman }\end{array}$ & $\begin{array}{c}4 \mathrm{ml} \text { pupuk hayati } \\
\text { Bacillus } / 10 \mathrm{ml} \\
\text { air/tanaman }\end{array}$ \\
\hline 1 & $45.0 \mathrm{c}$ & 72.2ab & $47.2 \mathrm{c}$ & $52.2 \mathrm{bc}$ & $75.6 a$ \\
\hline 2 & $42.8 \mathrm{~b}$ & $60.0 \mathrm{a}$ & $57.2 \mathrm{ab}$ & $51.1 \mathrm{ab}$ & $54.4 \mathrm{ab}$ \\
\hline 3 & $55.6 \mathrm{~b}$ & $72.2 \mathrm{ab}$ & $77.8 \mathrm{ab}$ & 94.4a & 94.4a \\
\hline 4 & $41.1 \mathrm{~b}$ & $83.3 \mathrm{ab}$ & 100.0a & 94.4a & $72.2 \mathrm{ab}$ \\
\hline 5 & $55.6 \mathrm{~b}$ & $100.0 \mathrm{a}$ & $72.2 \mathrm{ab}$ & $74.4 \mathrm{ab}$ & 94.4a \\
\hline 6 & $68.9 \mathrm{a}$ & $82.2 \mathrm{a}$ & $83.3 \mathrm{a}$ & $88.9 \mathrm{a}$ & $72.2 \mathrm{a}$ \\
\hline 7 & $55.6 b$ & $77.8 \mathrm{ab}$ & $74.4 \mathrm{ab}$ & 94.4a & 105.6a \\
\hline 8 & $55.6 \mathrm{~b}$ & 88.9a & $83.3 \mathrm{ab}$ & 94.4a & $83.3 \mathrm{ab}$ \\
\hline 9 & $52.2 b$ & $94.4 a$ & $105.6 a$ & $82.2 \mathrm{ab}$ & $88.9 \mathrm{ab}$ \\
\hline 10 & $57.8 \mathrm{~b}$ & $88.9 \mathrm{ab}$ & $88.9 \mathrm{ab}$ & 88.9ab & $100.0 \mathrm{a}$ \\
\hline 11 & $64.4 \mathrm{~b}$ & $116.7 \mathrm{a}$ & 105.6a & 111.1a & $88.9 \mathrm{ab}$ \\
\hline 12 & $50.0 \mathrm{~b}$ & $83.3 \mathrm{ab}$ & $105.6 \mathrm{a}$ & $100.0 \mathrm{a}$ & $100.0 \mathrm{a}$ \\
\hline 13 & $64.4 \mathrm{a}$ & 71.1a & $78.9 a$ & $84.4 \mathrm{a}$ & $88.3 \mathrm{a}$ \\
\hline 14 & $58.9 b$ & $66.7 \mathrm{~b}$ & $62.2 b$ & $82.2 \mathrm{ab}$ & 95.6a \\
\hline 15 & $64.4 \mathrm{a}$ & $66.7 \mathrm{a}$ & $88.9 \mathrm{a}$ & $83.3 \mathrm{a}$ & $81.1 \mathrm{a}$ \\
\hline
\end{tabular}

Keterangan: Angka-angka yang diikuti oleh huruf yang sama pada baris yang sama, tidak berbeda nyata menurut Uji DMRT taraf $5 \%$ 
da sadapan ke-11. Rata-rata KKK yang dihasilkan perlakuan 1-4 ml pupuk hayati Bacillus sekitar 26.3-33.3\%, sedangkan perlakuan kontrol menghasilkan KKK sekitar 28.0-34.0\% (Tabel 3). Kadar karet kering pada lateks tergantung pada beberapa faktor, yaitu jenis klon, umur pohon, waktu penyadapan, musim, suhu udara, serta letak tinggi dari permukaan laut (Purbaya et al., 2011).

\section{Produksi Karet Kering per Tanaman}

Produksi karet kering merupakan hasil perkalian antara volume lateks yang dihasilkan dengan kadar karet kering (KKK) yang terdapat di dalam lateks. Secara umum aplikasi pupuk hayati Bacillus dengan cara disemprot nyata meningkatkan produksi karet kering per tanaman pada sadapan ke-1 sampai 12. Rata-rata produksi karet kering per tanaman pada perlakuan 1-4 ml pupuk hayati Bacillus sekitar 14.2-36.9 g, sedangkan perlakuan kontrol hanya menghasilkan karet kering per tanaman sekitar 12.8-20.7 g (Tabel 4). Produksi karet kering per tanaman pada perlakuan pupuk hayati Bacillus meningkat karena produksi lateks per tanaman pada setiap kali sadapan meningkat.

Tabel 3. Pengaruh perlakuan pupuk hayati Bacillus dengan aplikasi semprot terhadap kadar karet kering (KKK)

\begin{tabular}{cccccc}
\hline & \multicolumn{5}{c}{ Kadar Karet Kering (\%) } \\
\cline { 2 - 6 } Sadapan ke- & Kontrol & $\begin{array}{c}1 \text { ml pupuk hayati } \\
\text { Bacillus/10 ml } \\
\text { air/tanaman }\end{array}$ & $\begin{array}{c}2 \text { ml pupuk hayati } \\
\text { Bacillus/10 ml } \\
\text { air/tanaman }\end{array}$ & $\begin{array}{c}3 \text { ml pupuk hayati } \\
\text { Bacillus/10 ml } \\
\text { air/tanaman }\end{array}$ & $\begin{array}{c}4 \text { ml pupuk hayati } \\
\text { Bacillus/10 ml } \\
\text { air/tanaman }\end{array}$ \\
\hline 1 & $28.3 \mathrm{a}$ & $30.0 \mathrm{a}$ & $30.0 \mathrm{a}$ & $30.7 \mathrm{a}$ & $30.0 \mathrm{a}$ \\
2 & $30.0 \mathrm{a}$ & $30.0 \mathrm{a}$ & $31.0 \mathrm{a}$ & $29.7 \mathrm{a}$ & $31.0 \mathrm{a}$ \\
3 & $32.3 \mathrm{a}$ & $29.7 \mathrm{a}$ & $32.7 \mathrm{a}$ & $32.3 \mathrm{a}$ & $30.3 \mathrm{a}$ \\
4 & $31.3 \mathrm{a}$ & $29.7 \mathrm{a}$ & $31.0 \mathrm{a}$ & $32.7 \mathrm{a}$ & $31.0 \mathrm{a}$ \\
5 & $33.3 \mathrm{a}$ & $33.0 \mathrm{a}$ & $30.7 \mathrm{a}$ & $31.7 \mathrm{a}$ & $32.7 \mathrm{a}$ \\
6 & $30.3 \mathrm{a}$ & $31.0 \mathrm{a}$ & $30.7 \mathrm{a}$ & $32.0 \mathrm{a}$ & $32.3 \mathrm{a}$ \\
7 & $30.0 \mathrm{a}$ & $31.3 \mathrm{a}$ & $31.0 \mathrm{a}$ & $33.0 \mathrm{a}$ & $31.7 \mathrm{a}$ \\
8 & $30.7 \mathrm{a}$ & $31.7 \mathrm{a}$ & $33.0 \mathrm{a}$ & $31.0 \mathrm{a}$ & $32.7 \mathrm{a}$ \\
9 & $32.7 \mathrm{a}$ & $32.3 \mathrm{a}$ & $30.0 \mathrm{a}$ & $32.3 \mathrm{a}$ & $31.0 \mathrm{a}$ \\
10 & $32.0 \mathrm{a}$ & $31.3 \mathrm{a}$ & $33.0 \mathrm{a}$ & $31.7 \mathrm{ab}$ & $32.0 \mathrm{a}$ \\
11 & $30.7 \mathrm{~b}$ & $31.7 \mathrm{ab}$ & $30.0 \mathrm{~b}$ & $31.7 \mathrm{a}$ & $29.7 \mathrm{a}$ \\
12 & $32.0 \mathrm{a}$ & $32.7 \mathrm{a}$ & $32.7 \mathrm{a}$ & $30.3 \mathrm{a}$ & $31.0 \mathrm{a}$ \\
14 & $31.0 \mathrm{a}$ & $31.0 \mathrm{a}$ & $30.0 \mathrm{a}$ & $29.7 \mathrm{a}$ & $26.3 \mathrm{a}$ \\
\hline
\end{tabular}

Keterangan: Angka-angka yang diikuti oleh huruf yang sama pada baris yang sama, tidak berbeda nyata menurut Uji DMRT taraf 5\%

Tabel 4. Pengaruh perlakuan pupuk hayati Bacillus dengan aplikasi semprot terhadap produksi karet kering per tanaman

\begin{tabular}{|c|c|c|c|c|c|}
\hline \multirow[b]{2}{*}{ Sadapan ke- } & \multicolumn{5}{|c|}{ Karet Kering/Tanaman (g) } \\
\hline & Kontrol & $\begin{array}{c}1 \mathrm{ml} \text { pupuk hayati } \\
\text { Bacillus } / 10 \mathrm{ml} \\
\text { air/tanaman }\end{array}$ & $\begin{array}{c}2 \mathrm{ml} \text { pupuk hayati } \\
\text { Bacillus } / 10 \mathrm{ml} \\
\text { air/tanaman }\end{array}$ & $\begin{array}{c}3 \mathrm{ml} \text { pupuk hayati } \\
\text { Bacillus } / 10 \mathrm{ml} \\
\text { air/tanaman }\end{array}$ & $\begin{array}{c}4 \mathrm{ml} \text { pupuk hayati } \\
\text { Bacillus } / 10 \mathrm{ml} \\
\text { air/tanaman }\end{array}$ \\
\hline 1 & $12.8 \mathrm{c}$ & 21.6ab & $14.2 \mathrm{bc}$ & $16.1 \mathrm{abc}$ & $22.7 \mathrm{a}$ \\
\hline 2 & $12.9 \mathrm{a}$ & $18.0 \mathrm{a}$ & $17.8 \mathrm{a}$ & $15.2 \mathrm{a}$ & $16.9 \mathrm{a}$ \\
\hline 3 & $17.8 \mathrm{~b}$ & $21.5 \mathrm{ab}$ & $25.4 \mathrm{ab}$ & $30.7 \mathbf{a}$ & 28.6a \\
\hline 4 & $13.0 \mathrm{~b}$ & $24.8 \mathrm{ab}$ & $31.4 a$ & $30.8 \mathrm{ab}$ & $22.3 \mathrm{ab}$ \\
\hline 5 & $18.6 b$ & $32.7 \mathbf{a}$ & $22.2 \mathrm{ab}$ & $23.9 \mathrm{ab}$ & $29.8 \mathrm{ab}$ \\
\hline 6 & $20.7 \mathrm{a}$ & $25.3 \mathrm{a}$ & $25.7 \mathrm{a}$ & $28.9 \mathrm{a}$ & $23.3 \mathrm{a}$ \\
\hline 7 & $16.7 \mathrm{c}$ & $24.3 \mathrm{abc}$ & $22.8 \mathrm{bc}$ & 31.3ab & 33.9a \\
\hline 8 & $17.1 \mathrm{~b}$ & $30.9 \mathrm{ab}$ & $31.7 \mathbf{a}$ & $26.6 \mathrm{ab}$ & $27.9 \mathrm{ab}$ \\
\hline 9 & $17.1 \mathrm{~b}$ & $30.9 \mathrm{ab}$ & $31.7 \mathbf{a}$ & $26.6 \mathrm{ab}$ & 27.9ab \\
\hline 10 & $18.4 b$ & $27.8 \mathrm{ab}$ & 29.3a & $27.5 \mathrm{ab}$ & 32.1a \\
\hline 11 & $19.7 \mathrm{~b}$ & $36.9 \mathrm{a}$ & $31.7 \mathbf{a}$ & $35.2 \mathrm{a}$ & 29.1ab \\
\hline 12 & $16.0 \mathrm{~b}$ & $27.4 a$ & 34.3a & 31.4a & 32.1a \\
\hline 13 & $19.7 \mathrm{a}$ & $21.8 \mathrm{a}$ & $23.5 \mathrm{a}$ & $26.0 \mathrm{a}$ & $26.1 \mathrm{a}$ \\
\hline 14 & $20.0 \mathrm{ab}$ & $21.7 \mathrm{ab}$ & $18.6 \mathrm{~b}$ & $24.4 \mathrm{ab}$ & $29.6 \mathrm{a}$ \\
\hline 15 & $17.9 \mathrm{a}$ & $19.1 \mathrm{a}$ & $18.3 \mathrm{a}$ & $23.3 \mathrm{a}$ & $21.3 \mathrm{a}$ \\
\hline
\end{tabular}

Keterangan: Angka-angka yang diikuti oleh huruf yang sama pada baris yang sama, tidak berbeda nyata menurut Uji DMRT taraf 5\% 


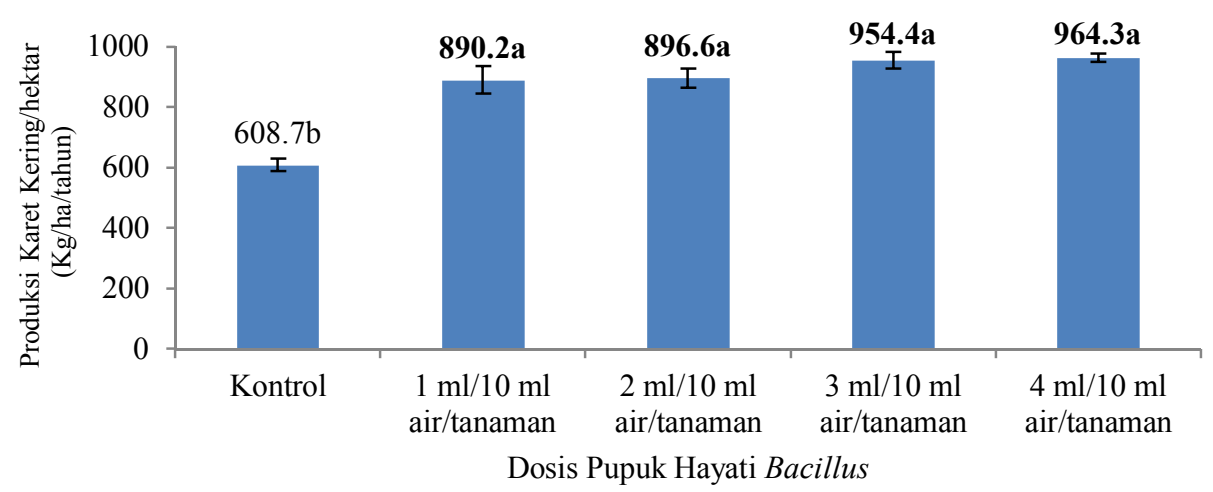

Gambar 2. Pengaruh pupuk hayati Bacillus dengan aplikasi semprot terhadap produksi karet kering per hektar per tahun

\section{Produksi Karet Kering per Hektar}

Dengan menggunakan asumsi tanaman disadap 3 hari sekali dengan populasi tanaman per hektar 360 tanaman dan rata-rata produksi karet kering seperti yang tercantum pada Tabel 4 , maka dapat diperoleh produktivitas tanaman seperti terlihat pada Gambar 2. Aplikasi 1-4 ml pupuk hayati Bacillus dengan cara di semprot nyata meningkatkan produksi karet kering per hektar. Perlakuan 1-4 $\mathrm{ml}$ pupuk hayati Bacillus menghasilkan produksi karet kering per hektar sekitar 890.2-964.3 kg/ha/tahun, sedangkan perlakuan kontrol hanya menghasilkan produksi karet kering sekitar $608.7 \mathrm{~kg} /$ ha/tahun. Tanaman karet yang disemprot 1-4 $\mathrm{ml}$ pupuk hayati Bacillus 46.25-58.42\% lebih tinggi dibandingkan perlakuan kontrol. Perlakuan $4 \mathrm{ml}$ pupuk hayati Bacillus menghasilkan produksi karet kering per hektar tertinggi dibandingkan perlakuan lain.

\section{KESIMPULAN}

Hasil penelitian menunjukkan bahwa aplikasi pupuk hayati dengan dioles maupun disemprot nyata meningkatkan produksi lateks, produksi karet kering per tanaman, dan hasil karet kering per hektar per tahun, tetapi tidak berpengaruh terhadap kadar karet kering (KKK). Aplikasi pupuk hayati Bacillus menyebabkan bidang sadap sehat dan lebih tahan terhadap serangan jamur.

\section{DAFTAR PUSTAKA}

Andriyanto, M., R. Tistama. 2014. Perkembangan dan upaya pengendalian kering alur sadap (KAS) pada tanaman karet (Hevea brasilensis). Warta Perkaretan. 33(2):89102.

Arja, A.R., Supijatno. 2018. Penyadapan tanaman karet (Hevea brasiliensis Mull-Arg.) di perkebunan karet Gurach Batu Estate
Asahan, Sumatera Utara. Bul. Agrohorti 6(1):1-9.

D'Auzac, J., H. Cretin, B. Marin, C. Lioret. 1982. A plant vacuolar system: the lutoids from Hevea brasiliensis latex. Physiol Veg. 20: 311-331.

Desnawati. 2006. Pemanfaatan Plant Growth Promoting Rhizobacteria (PGPR) Prospek menjanjikan dalam Berusaha Tani Hortikultura. Direktorat Perlindungan Tanaman Hortikultura, Jakarta.

Galingging, A.R.P., Charloq, F.E.T. Sitepu. 2017. Respon produksi lateks dalam berbagai waktu aplikasi pada klon karet metabolisme tinggi terhadap pemberian stimulant etilen ekstrak kulit pisang. J. Agroekoteknologi. 5(2):454-461.

Gao, X., Y. Gong, Y. Huo, Q. Han, Z. Kang, L. Huang. 2015. Endophytic Bacillus subtilis strain EIR-J is a promising biocontrol agent for wheat powdery mildew. BioMed Res. International. 1-8.

Gupta, V.P., H. Bochow, Dolej, I. Fischer. 1999. Plant Growth Promoting Bacillus subtilis Strain As Potential Inducer of Systemic Resistance in Tomato Against Fusarium wilt. Institute for Phytpathologi and Plant Protection. Berlin, German.

Habazar, T., Yaherwandi. 2006. Pengendalian Hayati Hama dan Penyakit Tumbuhan. Universitas Andalas, Padang.

Idris, E.E., D.J. Iglesias, M. Talon, R. Borris. 2007. Tryptophan dependent production of indole-3-acetic acid (IAA) affects level of plant growth promotion by Bacillus amyloliquefaciens FZB42. Molecular Plant Microbe Interaction. 20:619-626. 
Iskarlia, G.R., L. Rahmawati, U. Chasanah. 2014. Fungisida nabati dari tanaman serai wangi (Cymbopogon nardus) untuk menghambat pertumbuhan jamur pada batang karet (Hevea brasiliensis Muell. Arg). Polhasains Jurnal Sains dan Terapan Politeknik Hasnur. 3(1):1-8.

Jatnika, W., A.L. Abadi, L.Q. Aini. 2013. Pengaruh aplikasi Bacillus sp. dan Pseudomonas sp. terhadap perkembangan penyakit bulai yang disebabkan oleh jamur pathogen Peronoslerospora maydis pada tanaman jagung. J. HPT. 1(4): 19-29.

Lestari, P., Y. Suryadi, D.N. Susilowati, T.P. Priyanto, I.M. Samudra. 2015. Karakteristik bakteri penghasil asam indol asetat dan pengaruhnya terhadap vigor benih padi. Berita Biologi. 14(1):19-28.

Maulana, J.R., Fitriyadi, R. Fitriani. 2016. Sistem pakar diagnosis penyakit tanaman karet dengan metode Dempster-Shafer. JUTISI. 5(1): 877-1021.

Purbaya, M., T.I. Sari, C.A. Saputri, M.T. Fajriaty. 2011. Pengaruh beberapa jenis bahan penggumpal lateks dan hubungannya dengan susut bobot kadar karet kering dan plastisitas. Prosiding seminar Nasional AUOVER ke 3, 26-27 Oktober 2011.

Pusari, D., S. Haryanti. 2014. Pemanenan getah karet (Hevea brasiliensis Muell Arg) dan penentuan kadar karet kering (KKK) dengan variasi temperature pengovenan di PT. Djambi Waras Jujuhan kabupaten Bungo, Jambi. Bul. Anatomi dan Fisiologi 22(2):64-74.

Puspita, F., D. Zul, A. Khoiri. 2013. Potensi Bacillus sp. asal rhizosfer Giam Siak Kecil Bukit Batu sebagai rhizobacteria pemacu pertumbuhan dan antifungi pada pembibitan kelapa sawit. Prosiding Seminar Nasional, Pekanbaru.
Rosenblueth, M., E. Martinez-Romero. 2008. The American phytopathological society. MPMI. 19(8):827-837.

Semangun, H. 1990. Penyakit Tanaman Kebun di Indonesia. Gajah Mada University, Yogyakarta.

Syakir, M., S. Damanik, M. Tasma, Siswanto. 2010. Budidaya dan Pasca Panen Karet. Bogor.

Sulistiani, H., K. Muludi. 2018. Penerapan metode certainty factor dalam mendeteksi penyakit tanaman karet. Jurnal Pendidikan Teknologi dan Kejuruan. 15(1):51-60.

Suriani, A. Muis. 2016. Prospek Bacillus subtilis sebagai agen apengendalian hayati pathogen tular tanah pada tanaman jagung. J. Litbang. Pert. 35(1): 37-45.

Tistama, R., T.H.S. Siregar. 2005. Perkembangan penelitian stimulant untuk pengakiran lateks Hevea brasiliensis. Wrt. Perkrt. 24(2):45-57.

Wang, S.L., W.T. Chang. 1997. Purification and characterization of two biofungsional chitinases/lysozymes extracellularly produced by Pseudomonas aeruginosa K187 in a shrimp and crab shell powder medium. Appl. And Environ. Microbial. 63(2): 380-386.

Woelan, S., Sayurandi, A. Pasaribu. 2013. Karakter fisiologi, anatomi, pertumbuhan, dan hasil lateks klon IRR SERI 300. J. Penelitian Karet 31(1):1-12.

Zhu, J., Z. Zhang. 2009. Ethylene stimulation of latex production in Hevea brasiliensis. Plant Signaling \& Behaviour. 4(11):10721074. 